\title{
ARCHITECTURAL DECORATION AND SMALL FORMS IN DRANDA CHURCH: NEW FINDINGS ${ }^{1}$
}

\author{
Ekaterina Yu. Endoltseva \\ Institute of Oriental Studies, RAS, Moscow, Russian Federation \\ Dorotheos Dbar (Archimandrite) \\ Aristotle University, Thessaloniki, Greece; \\ Abkhazian Institute for Humanities, Academy of Sciences of Abkhazia, Sukhum, Abkhazia
}

\begin{abstract}
Introduction. This article deals with the altar barrier from the medieval church in Dranda village (Abkhazia). It is not preserved in its original form. Two slabs with figurative compositions were published by countess P. S. Uvarova at the end of the $19^{\text {th }}$ century. Then they were lost.

Methods. The modern researchers can analyze them only due to photo types made by the countess. Some fragments from Dranda church are now preserved in the collection of the Abkhazian State Museum in Sukhum. One new fragment (which was not known before) with the representation of the Jonas prophet (devoured by the sea monster) has been discovered in the collection of the Archaeological Museum of the Saint Metropolis of Abkhazia (New Athos). There are also four other fragments of the architectural decoration from the Dranda church.

Analysis. Some of them could possibly be part of the altar barrier. The rest of the fragments were probably from the outer or inner facing of the same church. The article also deals with the problem of the date of the rare image of prophet Jonas. The fragment can be dated by the $10^{\text {th }}$ century. The researchers dispute the date for the other fragments of the altar barrier.

Results. The authors of the article incline to the $10^{\text {th }}$ century for all the fragments of the shattered altar barrier. Father Dorotheos Dbar analyzed information about the history and origin of the reliefs in question. E. Yu. Endoltseva made iconographical research of the carved images. Jonas.

Key words: architectural decoration, Abkhazia, altar barrier, outer facing, Christian iconography, whale, prophet
\end{abstract}

Citation. Endoltseva E.Yu., Dbar D. (Archimandrite). Architectural Decoration and Small Forms in Dranda Church: New Findings. Vestnik Volgogradskogo gosudarstvennogo universiteta. Seriya 4, Istoriya. Regionovedenie. Mezhdunarodnye otnosheniya [Science Journal of Volgograd State University. History. Area Studies. International Relations], 2018, vol. 23, no. 5, pp. 196-209. (in Russian). DOI: https://doi.org/10.15688/jvolsu4.2018.5.18

АРХИТЕКТУРНАЯ ДЕКОРАЦИЯ И МАЛЫЕ ФОРМЫ ЦЕРКВИ В ДРАНДЕ: НОВЫЕ ДАННЫЕ ${ }^{1}$

\section{Екатерина Юрьевна Ендольцева}

Институт востоковедения РАН, г. Москва, Российская Федерация

\section{Дорофей Дбар (архимандрит)}

Университет им. Аристотеля, г. Салоники, Греция; Абхазский институт гуманитарных исследований Академии наук Абхазии, г. Сухум, Абхазия

Аннотация. Статья посвящена алтарной преграде из церкви в селе Дранда (Республика Абхазия). В первоначальном виде она не сохранилась, до наших дней дошли лишь ее фрагменты. Две плиты с фигуративны- 
ми композициями были опубликованы П. С. Уваровой в конце XIX в., затем они были утеряны и известны современным исследователями лишь по фототипиям, сделанным исследовательницей. Несколько фрагментов из Дранды (возможно, от алтарной преграды) хранятся в фондах Абхазского государственного музея (г. Сухум). Новый, ранее неизвестный фрагмент с изображением пророка Ионы, поглощаемого китом, хранится в фондах Церковно-археологического музея Священной Митрополии Абхазии (Новый Афон). В этом же собрании обнаружены еще 4 фрагмента архитектурной декорации из церкви в Дранде, часть которых также могла составлять алтарную преграду. Оставшиеся фрагменты, видимо, принадлежали к внешней (хотя других данных о присутствии внешней декорации в Дранде нет) или внутренней облицовке этой церкви. В статье рассматриваются возможности датировки редкого с иконографической точки зрения изображения с Ионой, поглощаемым китом. Вероятно, фрагмент с этой сценой можно отнести к Х веку. Относительно датировки других фрагментов алтарной преграды из Дранды исследователи высказывали различные соображения. Авторы статьи склонны относить их также к X веку. Фрагмент с изображением Ионы, поглощаемого китом, относится к редкому иконографическому типу, который, однако, известен с раннехристианских времен на территории Малой Азии. В данной ситуации кит изображен дважды, в первом случае из его пасти торчат ноги пророка, во втором - его торс с воздетыми руками. В раннехристианском и позднесредневековом искусстве большее распространение получил другой тип изображения этого эпизода. Обычно его изображают в двух сценах: гребцы сбрасывают Иону с корабля, отдых Ионы (под раскидистым деревом) во чреве кита. О. Дорофей Дбар обрабатывал информацию, касающуюся происхождения выявленных известняковых блоков и их истории. Е.Ю. Ендольцева сделала иконографический анализ представленных изображений.

Ключевые слова: архитектурная декорация, Абхазия, алтарная преграда, внешняя облицовка, христианская иконография, кит, пророк Иона.

Цитирование. Ендольцева Е. Ю., Дбар Д. (архимандрит). Архитектурная декорация и малые формы церкви в Дранде: новые данные // Вестник Волгоградского государственного университета. Серия 4, История. Регионоведение. Международные отношения. - 2018. - Т. 23, № 5. - С. 196-209. - DOI: https://doi.org/ 10.15688/jvolsu4.2018.5.18

Введение. Некоторые фрагменты архитектурной декорации и алтарной преграды, происходящие из церкви в Дранде (Республика Абхазия), были известны научному сообществу начиная со второй трети XIX века. Они были опубликованы и атрибутированы. Несмотря на то что датировка нередко вызывала споры, большинство исследователей относило их к раннехристианскому периоду или к эпохе Средневековья. Вызывал дискуссии также вопрос о том, были ли все известные фрагменты выполнены в одно время, или их можно соотнести с различными этапами украшения здания церкви. Настоящее исследование посвящено новым, ранее неизвестным фрагментам каменной резьбы, украшавшим церковь в Дранде, которые в настоящий момент хранятся в фондах Церковно-археологического музея Священной Митрополии Абхазии (Новый Афон). Анализ этих фрагментов позволяет по-новому взглянуть на проблему датировки и реконструкции резной алтарной преграды из церкви в Дранде, а также дает дополнительные сведения по поводу ее архитектурной декорации.

Среди основных целей предлагаемого исследования - определить время исполнения ранее неизвестных фрагментов архитектурной декорации церкви в Дранде и ее алтарной преграды. Одной из основных задач является определение места фрагментов каменной резьбы из вышеозначенной церкви в художественной культуре ее времени, а также поиск иконографических истоков наиболее интересных изображений.

Методы. Для успешного решения поставленных целей и задач необходим комплексный подход, который предполагает анализ технических и стилистических особенностей изучаемых резных изображений, а также поиск их иконографических аналогий. Немаловажно также проследить историю развития наиболее интересных сюжетов в рамках христианской культуры поздней Античности и Средневековья.

Как уже было упомянуто выше, алтарная преграда и фрагменты архитектурной декорации из Дранды привлекают внимание исследователей уже давно. Первым сообщил об этой лапидарной коллекции Фредерик Дюбуа де Монпере, известный путешественник, этнограф и археолог. По результатам своего путешествия по Крыму и Кавказу ученый из- 
дал в Париже (1839-1843) обширный шеститомный труд «Путешествие вокруг Кавказа» (полное название - «Voyage autour du Caucase, chez les Tcherkesses et les Abkhases, en Colchide, en Géorgie, en Arménie et en Crimée») [18, p. 318]. В том месте этого сочинения, где упоминается храм в Дранде, Ф. Дюбуа де Монпере подробно описывает состояние алтарной преграды и характер ее разрушений на момент своего посещения [18, p. 318]. Другое описание алтарной преграды в церкви в Дранде оставил известный археолог и путешественник С. Саблин [11, с. 32]. Он описал не только состояние виденной им алтарной преграды, но и характер резного убранства церкви снаружи. Позже графиня П.С. Уварова, известный археолог и исследовательница древностей Кавказа, опубликовала фототипии двух ныне утерянных плит из алтарной преграды [12, с. 30 , табл. XII]. Она также впервые предложила версии их датировки. Еще один фрагмент этой конструкции был опубликован уже в советское время Л.Г. Хрушковой [13, с. 270-273, табл. LXIII, 1, табл. LXII, 1]. В двух своих работах, посвященных каменной резьбе Абхазии, исследовательница предлагает различные версии датировки разных фрагментов алтарной преграды из церкви в Дранде [14, c. $38 ; 20$, p. 77-78, pl. 51, a]. Однако предлагаемые версии можно оспорить, что и делает А.Ю. Виноградов, исходя из стилистического анализа композиции на двух плитах [3]. Кроме того, в прошлом году вышло исследование грузинских авторов, посвященное средневековой грузинской скульптуре, где упоминается фрагмент алтарной преграды из Дранды с изображением пророка Ионы [17, p. 111]. Эта деталь отнесена к памятникам $\mathrm{X}$ века $[17$, p. 111]. Жаль, что в этой публикации отсутствуют сведения об актуальном местонахождении этого фрагмента, а также о его технических особенностях. Низкие по качеству фотографии (к тому же, их мало) затрудняют дальнейшее изучение этого уникального фрагмента.

Анализ. Ф. Дюбуа де Монпере первым дает подробное описание интересующей нас алтарной преграды и степени ее сохранности. Исследователь отмечает, что она была составлена из «колонок белого мрамора и антаблемента, ее части были соединены метал- лическими стяжками» [18, p. 318]. Швейцарский археолог видел темплон в руинированном состоянии, в его время in situ оставались в хорошей сохранности только верхняя часть конструкции, где изначально не было металлических элементов [18, p. 318]. С. Саблин в своем описании церкви в Дранде, опубликованном в 1846 г., отмечал, что алтарная преграда была отделана шестью большими из белого мрамора колоннами, обломки которых он видел лежавшими внутри церкви и около нее $[11$, с. 32]. Этот же автор утверждает, что оконные проемы Драндской церкви снаружи были «обделаны мрамором с рельефами и украшениями изящной работы» [11, с. 32]. Графиня П.С. Уварова отмечает, что фрагменты этой преграды (резные колонки) были найдены ею уже среди строительного мусора во дворе храма [12, с. 30]. А две известняковые плиты хранились в ее время у г. Веденского, начальника Сухумского отдела [12, c. 30]. Нынешнее местонахождение этих артефактов неизвестно. П.С. Уварова сделала фототипии этих двух плит и их опубликовала. Еще один фрагмент темплона из церкви в селе Дранда был опубликован Л. Г. Хрушковой [13, c. 270-273, табл. LXIII, 1, табл. LXII, 1]. Это известняковый блок (у Л.Г. Хрушковой он ошибочно назван мраморным), украшенный мотивом арочек. По словам исследовательницы, «он лежал на линии алтарного ограждения, вероятно, это и есть его первоначальное положение» $[13$, с. 272].

Таким образом, задача анализа стилистических и технических особенностей двух самых репрезентативных фрагментов рассматриваемого темплона, плит с фигуративными композициями, осложняется тем, что его возможно делать только по опубликованным фототипиям П.С. Уваровой. К сожалению, невозможно даже определить точные размеры этих двух артефактов. Последнее обстоятельство усложняет возможную реконструкцию памятника. На первой плите изображен благословляющий Христос на троне между идущих к Нему ангелов (сохранились два с правой стороны от зрителя) [12, c. 30]. Фигура Христа представлена монументально. Его голова показана фронтально в обрамлении крестчатого нимба. Складки одеяния Христа показаны глубокими парал- 
лельными бороздками. Они моделируют тело достаточно натуралистично, благодаря чему можно определить позу фигуры Христа. Он величаво восседает на троне. Одеяния двух сохранившихся ангелов и их крылья выполнены в той же технике, что и облачение Христа. Подобно Христу оба ангела показаны фронтально. Их правые руки воздеты и обращены в сторону Христа, левые - находятся на уровне груди.

На второй плите представлен, вероятно, Деисус. Сохранились изображения Христа и Богоматери (в профиль). Каждая фигура помещена в богато декорированную нишу, увенчанную фронтоном треугольной формы, их разделяют разнообразные по орнаменту пилястры. Христос показан стоящим, вокруг его головы - крестчатый нимб. Его фигура представлена фронтально. Складки хитона и гиматия так же, как и на первой плите, позволяют определить его позу. Его правая рука воздета, как у ангелов на первой плите, левая прикровенна и согнута в локте на уровне груди. Фигура Богоматери показана в профиль. По росту она ниже Христа, ее прикровенные руки обращены к Нему. Пилястры, поддерживающие фронтоны сохранившихся частей аркатуры, богато декорированы. Тело обоих пилястров украшено углублением треугольной формы, составленным из растительных мотивов. Капитель большего пилястра, разделяющего фигуры Христа и Богоматери, дополнительно орнаментирована мотивом двух листьев, показанных в профиль и обращенных друг к другу. База этого пилястра обозначена дополнительным декоративным элементом тремя небольшими арочками с полукруглым завершением. Тело крайнего пилястра, замыкающего композицию со стороны Богоматери, покрыто четырьмя рядами прямоугольных арочек, скомпонованных по две.

Нет единого мнения по поводу датировки этих двух плит. П.С. Уварова высказывает предположение о том, что две плиты были вырезаны в разные эпохи. Первую она считала работой «древнехристианских мастеров», вторую - относила к более позднему времени [12, с. 30]. Л.Г. Хрушкова датирует первую плиту V в. [13, с. 271] или VI в. [14, с. 38 ; 20, p. 77-78], а вторую, как и фрагмент с мотивом арочек, относит к Х веку [20, p. 78].
А.Ю. Виноградов не соглашается с этой версией датировки двух плит и резонно возражает, что «стиль рельефов одинаков...: сходны проработка складок, тип головы и нимба Христа, орнаментация с характерным килевидным завершением» [3]. Исследователь датирует обе плиты IX-XI веками [3, с. 130].

В фондах Церковно-археологического музея Священной Митрополии Абхазии, в Новоафонском монастыре, хранятся 5 фрагментов архитектурной декорации из церкви в Дранде ${ }^{2}$. На первом из них (рис. 1,2 ), известняковом блоке прямоугольной формы (размеры фронтальной части $-22 \times 18$ см, боковые стороны $-23 \times 18$ и $16 \times 15,5$ см и $16 \times 16$ см), который, вероятнее всего, принадлежал алтарной преграде, на фронтальной части вырезан стилизованный растительный орнамент. Он несколько напоминает тот мотив, что украшает капитель пилястра, разделяющего фигуры Христа и Богоматери, на второй плите, опубликованной П.С. Уваровой.

На втором, также известняковом блоке (рис. $3,4,5)$ (размеры фронтальной части $47 \times 19$ см, остальные грани $-21,5 \times 15,5 \mathrm{~cm}$, $21,5 \times 18 \mathrm{~cm}, 15,5 \times 21,5 \mathrm{~cm}, 21,5 \times 16 \mathrm{~cm}$, $21,5 \times 14$ см), вырезаны арочки, чередующиеся со сдвоенными полуколонками. Этот фрагмент также мог быть частью алтарной преграды. Полукруглые завершения арочек отделены друг от друга каплевидными декоративными элементами. Этот фрагмент несколько напоминает блок, опубликованный Л.Г. Хрушковой в 2002 году [13, табл. LXIII, 1]. Еще 5 фрагментов известняковых блоков, украшенных подобным арочным мотивом, хранились до реконструкции Абхазского государственного музея в его фондах (инвентарные карточки № 81-96) ${ }^{3}$.

Третий фрагмент (рис. 6, 7) изображает сдвоенные полуколонки со сноповидными капителями (размеры фронтальной части $26 \times 24$ см, верхняя грань $-25 \times 16$ см, боковые грани $-25 \times 18$ см и $26 \times 18$ см). Фрагмент известнякового блока с подобной декорацией также хранился в фондах Абхазского государственного музея в г. Сухуме до его реконструкции ${ }^{4}$. Кроме того, три аналогичных фрагмента выставлены в витрине в притворе храма в Дранде. Там, как это обозначено в надписи, собраны «фрагменты наружной облицовки храма». 
Четвертый фрагмент (рис. 8, 9) не похож по стилю и материалу на остальные. Скоpeе всего, его можно отнести к более раннему времени. Это мраморный блок (единственный из пяти) со стилизованным растительным орнаментом, напоминающим орнамент на капители полуколонки на утерянной плите с Деисусом, опубликованной П.С. Уваровой (размеры фронтальной части $-27 \times 16 \mathrm{~cm}$, боковые части $-16 \times 27$ см и $17 \times 16$ см).

Последний фрагмент представляет наибольший интерес (рис. 10, 11). Впервые его, немного опередив нас, опубликовали в 2017 г. грузинские исследователи [17, p. 111]. Однако описание сделано небрежно (авторы ошибочно называют фрагмент капителью), неправильно указано место его хранения, нет размеров, фотографий мало и они плохого качества, нет анализа иконографических истоков этой уникальной композиции ${ }^{5}$.

На круглом в сечении известняковом блоке (возможно, он был базой колонки) представлена сцена (достаточно редкая по иконографии), где последовательно показано «Поглощение Ионы китом» (размеры - внутренний диаметр -27 см, внешний диаметр $-32 \mathrm{~cm}$, высота - 23 см). В данном случае кит показан дважды. Его тело опоясывает круглый в сечении известняковый блок. Хвост этого животного заканчивается у морды его двойника. В одном случае из пасти кита показывается торс пророка Ионы с воздетыми руками, во втором - в ней исчезают его ноги. Голова пророка показана фронтально, у него сужающееся книзу лицо, высокий лоб с залысиной, остроконечная борода, большого размера миндалевидные глаза с высверленным зрачком, полукруглые массивные брови. Одеяние, покрывающее воздетые руки, обозначено параллельными бороздками. Подобным же образом, судя по всему, было показано облачение Христа и ангелов на первой плите, опубликованной П.С. Уваровой, а также были обозначены хитон и гиматий Богоматери и Христа на второй плите.

Кит показан как гибридное существо. Он напоминает рыбу с чешуйчатым телом и хвостом (чешуя показана крупными диагональными ступенчатыми линиями, которые образуют острый угол на условной линии, обозначающей середину тела рыбы вдоль всей дли- ны). У него зубастая пасть с клыками, острые хищные уши, круглые глаза навыкате, стилизованные крылья (показаны параллельными вертикальными насечками в верхней части тела у головы), когтистые львиные лапы. Такие гибридные существа нередко встречаются в орнаментации христианских храмов Средневековья в Закавказье. К примеру, похожее существо, в котором улавливается сходство с Сасанидским «сенмурвом» [19], изображено в сцене поглощения пророка Ионы китом на южном фасаде храма св. Креста на о. Ахтамар. Судя по всему, такого рода гибридные мифологические существа, «изображения которых были особенно распространены в декоративном и прикладном искусстве исламского периода, проникли к соседним христианским народам благодаря быстрому развитию городов и торговли» [19]. Как справедливо отмечают 3. Акопян и Л. Микаелян, подобного рода гибридные мифологические существа стали особенно часто встречаться на памятниках Закавказья в период Высокого Средневековья. «Самые ранние виды таких существ были вырезаны на церкви св. Креста на о. Ахтамар в начале $\mathrm{X}$ века. Они стали распространяться между концом X и началом XI в., становясь особенно многочисленными к XIII веку» [19]. Интересно, что, начиная с периода иконоборчества, гибридные мифологические существа, в частности сенмурв, часто изображаются не только в Закавказье, но и на территории всего христианского мира, от Византии до Западной Европы. «В период Высокого Средневековья иранские иконографические темы проникают в Византию и частично в Западную Европу через посредство исламского искусства, которое, в свою очередь, сформировалось под влиянием Сасанидского искусства» [19].

Среди ближайших иконографических и стилистических аналогий рассматриваемой композиции следует указать, прежде всего, на рельеф из церкви в Кванса-Джвари (X в.) [1, c. 81-86, ил. 69]. На прямоугольной известняковой плите представлен свернувшийся клубком двуглавый зубастый змей. Из пасти одной из его голов виден торс пророка Ионы с воздетыми руками, из пасти другой - торчат ноги пророка. В отличие от изображения из Дранды, в данном случае определенно пока- 
зан змей. У него отсутствуют уши хищника, клыки, крылья и когтистая лапа. Часть рассматриваемой композиции (из пасти кита торчит торс Ионы с воздетыми руками) появляется также на южном фасаде храма в Хахули (2-я половина Х в.) [1, ил. 118].

Схожее с Драндским китом гибридное существо показано также на рельефе из Тхаба-Ерды (Х в.) [9, с. 59] и на рельефе из Касагина [10, с. 82]. У него также видны зубастая пасть, когтистая лапа, острые уши и стилизованное крыло. Правда, в данном случае это не кит, а скорее всего существо, по смыслу более близкое к грифону [7]. Интересно, что на самых ранних христианских памятниках (рубеж III-IV вв.) уже появляется сцена с изображением пророка Ионы, поглощаемого китом. Мало того, с самого начала ее истории в искусстве можно зафиксировать два различных иконографических извода. В одном случае, как, например, на римском саркофаге конца III в. [16, № 35], история пророка Ионы показана в двух сценах (Иону сбрасывают с корабля и Иона возлежит во чреве кита). Этот тип изображения данного сюжета широко распространился. Он встречается на многих памятниках христианского искусства не только в позднеантичный период, но и в Средневековье (к примеру, многочисленные римские саркофаги IV в. [16, № 11, 44, 77, 770], Равеннский диптих VI в., южный фасад церкви св. Креста на о. Ахтамар и многие другие).

Во втором случае (то есть в том, что мы видим, к примеру, на фрагменте алтарной преграды из Дранды) показан момент поглощения пророка морским чудищем и его исторжение из чрева. Дважды представлена зубастая пасть кита. Из одной - торчит торс Ионы с воздетыми руками, из другой - только его ноги. Самое раннее изображение этого извода встречается, к примеру, в Малой Азии III в. (280-290 гг., парная скульптура из Художественного музея в Кливленде) [4, с. 123]. Таким образом, иконографические истоки изображения пророка Ионы на фрагменте алтарной преграды из Дранды берут свое начало в раннехристианском искусстве эллинистического толка.

Если рассуждать о стилистически близких изображениях, то необходимо упомянуть несколько фигуративных композиций, происхо- дящих также из соседних с Драндой районов Абхазии. Среди них, к примеру, плита, обнаруженная П.С. Уваровой в церкви из с. Ольгинское [12, с. 19]. При осмотре церкви и ее расчистке были обнаружены следы алтарной преграды, четыре резных столбика и три известняковые плиты [12, с. 20]. Изображения алтарных столбиков, к сожалению, не были опубликованы. П.С. Уварова опубликовала фототипии трех резных плит. Одна из них, с изображением литургии, хранится в настоящее время в Национальном музее Грузии им. С. Джанашиа [21, p. 38]. На фототипии П.С. Уваровой [12, с. 21, рис. 10] видны три фигуры, сохранившиеся в полный рост в архитектурном пейзаже, представляющем из себя аркаду. В нижней части аркады - арочный мотив, сходный с тем, что встречается на фрагменте алтарной преграды из Дранды с изображением Деисуса (база пилястры, что отделяет Христа от Богоматери). Верхняя часть аркады составлена из узоров растительного происхождения. На фототипии П.С. Уваровой в крайней слева нише видна фигура ангела (ныне сохранилась только нижняя часть ангела), благословляющего фронтально представленного святителя в позе оранта в центральной нише. В правой нише представлен диакон с кадилом. Верхняя часть плиты с растительным орнаментом и головой ангела утеряна. Трактовка складок облачения святителя сходна с тем, как показаны складки на одеяниях Христа и двух ангелов на первой плите алтарной преграды из Дранды. Лицо святителя, его воздетые руки стилистически близки к изображению торса пророка Ионы, поглощаемого китом, на круглом в сечении основании столбика из фондов Церковно-археологического музея Священной Митрополии Абхазии. У святителя такой же, как у Ионы, высокий лоб с залысинами, большие миндалевидные глаза с высверленными зрачками, сужающееся книзу лицо и остроконечная бородка. Аналогичным образом выполнены и складки одежды на воздетых руках святителя и пророка Ионы.

П.С. Уварова датирует все три плиты из села Ольгинского XII-XIII веками [12, с. 20]. Г.В. Алибегашвили датирует эту плиту серединой Х века [2]. Грузинские исследователи неверно пишут о происхождении этой 


\section{ВОПРОСЫ КУЛЬТУРЫ ВИЗАНТИИ}

плиты, для них она происходит из окрестностей Сухума или из Бедии [1, с. 88]. Р. Шмерлинг также датирует этот памятник серединой X века [15, с. 76]. Л.Г. Хрушкова соглашается с этой датировкой $[14$, с. 86-96; 20, p. 108].

Другое аналогичное изображение удалось обнаружить в фондах Абхазского государственного музея [5; 6]. На плите с изображением предположительно Сна Иосифа [6] тот персонаж, которого ангел тянет за бороду (Иосиф), имеет те же черты лица, что и пророк Иона и святитель на рассматриваемых выше памятниках. У него тоже высокий лоб, большие миндалевидные глаза, остроконечная бородка. Сходным образом трактованы складки его хитона и ткань на воздетых руках. Эту плиту благодаря найденным в Клермон-Ферране аналогиям можно отнести к XIXII векам [6, с. 181].

Выводы. Таким образом, рассматриваемый рельеф с Ионой из фондов Церковноархеологического музея Священной митрополии Абхазии (Новый Афон), видимо, можно отнести к Х в. (как об этом свидетельствуют наиболее близкие иконографические аналогии). Если согласиться с точкой зрения А.Ю. Ви- ноградова об одновременности исполнения рельефов на двух известняковых плитах, опубликованных П.С. Уваровой, то можно, вероятно, считать все известные нам фрагменты алтарной преграды из Дранды выполненными в один и тот же исторический период. Учитывая анализ сцены на блоке с Ионой, этот темплон можно датировать X веком. Данной датировке не противоречит наличие одной мраморной детали, так как исследователи, которые видели преграду в лучшей степени сохранности, отмечали в ней наличие как известняковых, так и мраморных деталей.

\section{ПРИМЕЧАНИЯ}

${ }^{1}$ Опубликовано в виде тезисов [8].

${ }^{2}$ CM.: https://anyha.org/drandatwy-anyhadekor-afragmentkua/.

${ }^{3}$ Е.Ю. Ендольцева благодаря любезности М.К. Инал-Ипа посетила фонды Абхазского государственного музея в октябре 2008 года.

${ }^{4}$ Инв. № 81-96.

${ }^{5}$ Не указан и сам источник снимков, хотя очевидно, что это сайт Новоафонского монастыря (https://anyha.org/drandatwy-anyha-dekorafragmentkua/). 


\section{ПРИЛОЖЕНИЕ}

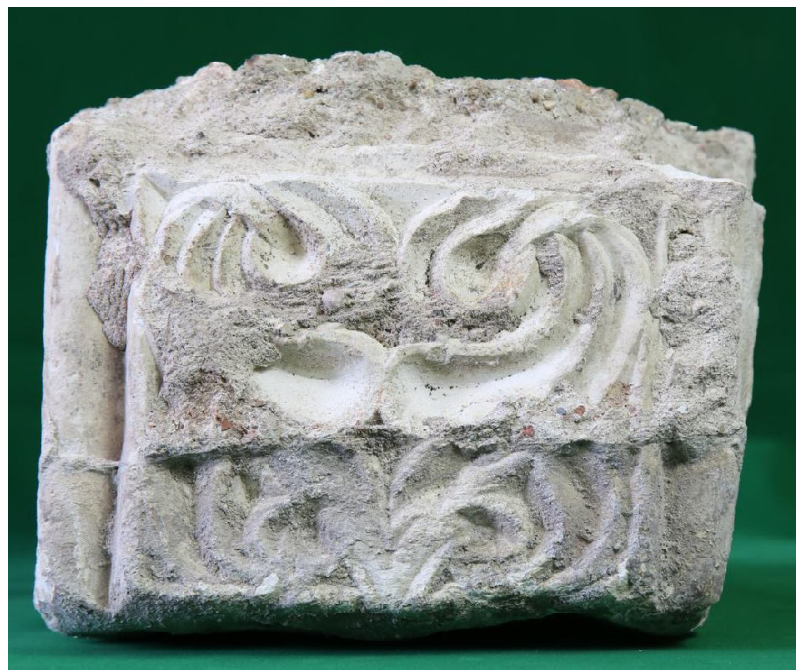

Рис. 1. Фрагмент резьбы из фондов Церковно-археологического музея

Священной Метрополии Абхазии (Новый Афон). Известняк. Рисунки 1-9 - фото Г. Захарцева

Fig. 1. Fragment of carving from the funds of the Church and Archaeological Museum of Holy Metropolis of Abkhazia (New Athos). Limestone. Figures 1-9 - photo by G. Zakhartsev

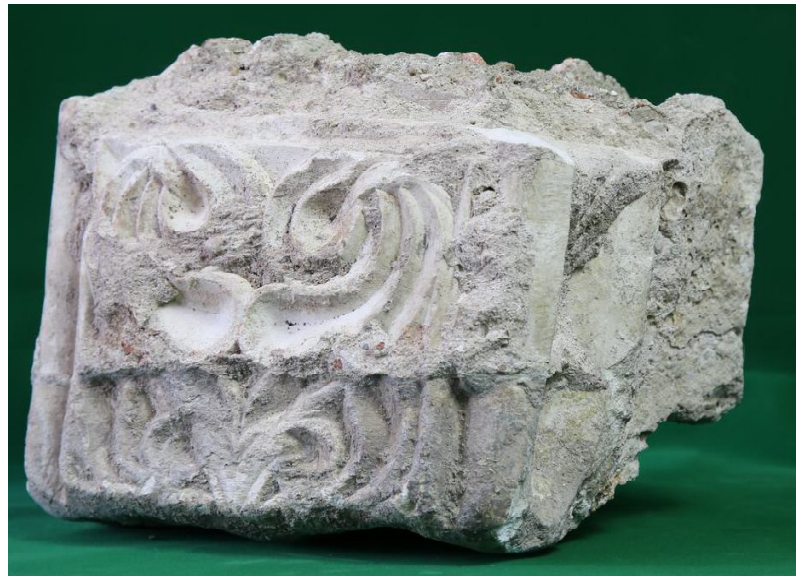

Рис. 2. Фрагмент резьбы из фондов Церковно-археологического музея Священной Метрополии Абхазии (Новый Афон). Известняк

Fig. 2. Fragment of carving from the funds of the Church and Archaeological Museum of Holy Metropolis of Abkhazia (New Athos). Limestone

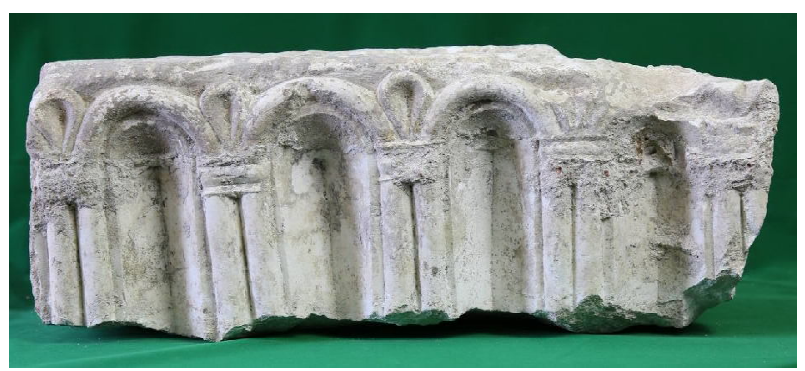

Рис. 3. Фрагмент алтарной преграды из фондов Церковно-археологического музея Священной Метрополии Абхазии (Новый Афон). Известняк

Fig. 3. Fragment of altar barrier from the funds of the Church and Archaeological Museum of Holy Metropolis of Abkhazia (New Athos). Limestone 


\section{ВОПРОСЫ КУЛЬТУРЫ ВИЗАНТИИ}

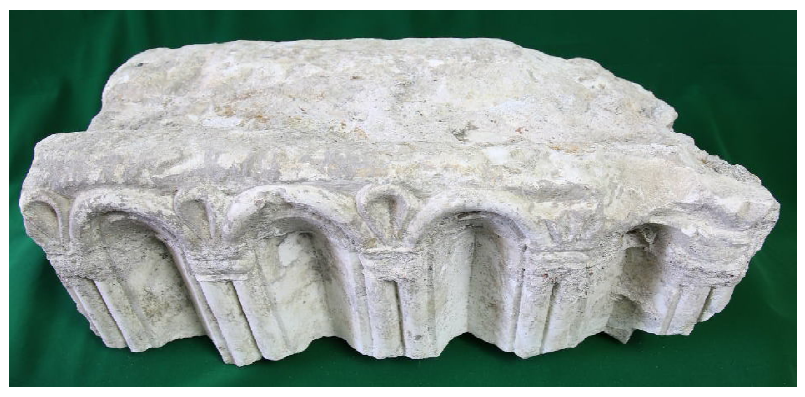

Рис. 4. Фрагмент алтарной преграды из фондов Церковно-археологического музея Священной Метрополии Абхазии (Новый Афон). Известняк

Fig. 4. Fragment of altar barrier from the funds of the Church and Archaeological Museum of Holy Metropolis of Abkhazia (New Athos). Limestone

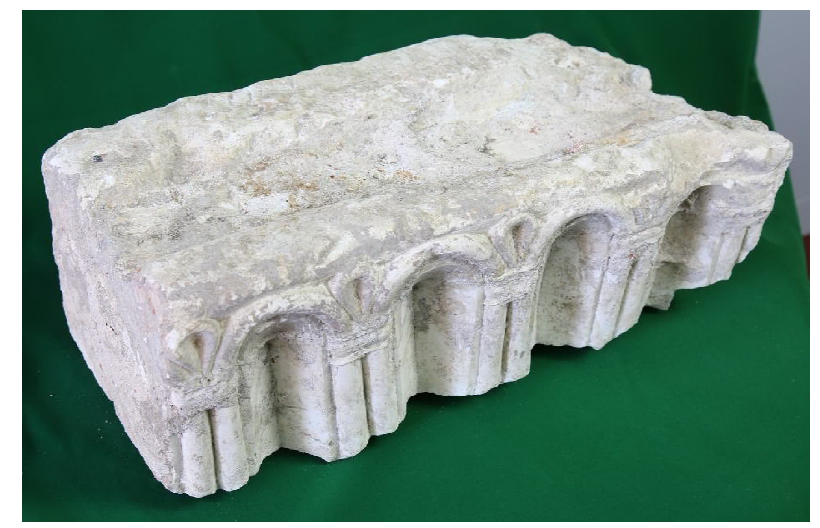

Рис. 5. Фрагмент алтарной преграды из фондов Церковно-археологического музея Священной Метрополии Абхазии (Новый Афон). Известняк

Fig. 5. Fragment of altar barrier from the funds of the Church and Archaeological Museum of Holy Metropolis of Abkhazia (New Athos). Limestone

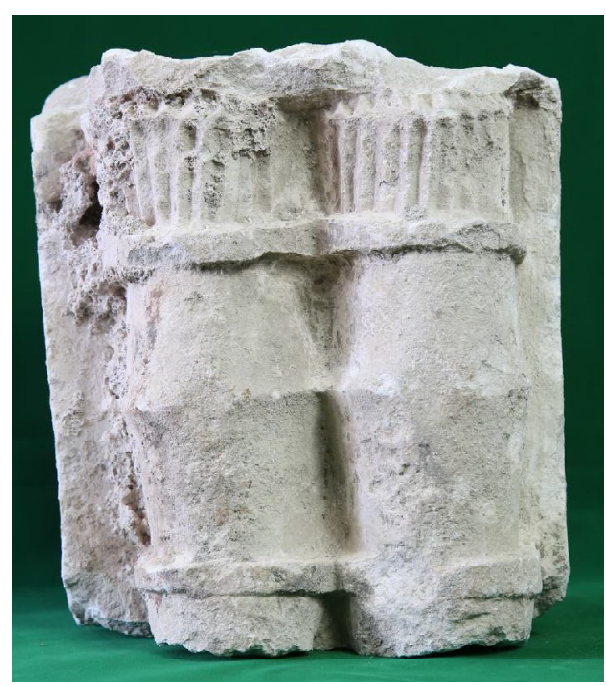

Рис. 6. Фрагмент архитектурной декорации из фондов Церковно-археологического музея

Священной Метрополии Абхазии (Новый Афон). Известняк

Fig. 6. Fragment of architectural decoration from the funds of the Church and Archaeological Museum of Holy Metropolis of Abkhazia (New Athos). Limestone 
Е.Ю. Ендольиеева, Д. Дбар (архимандрит). Архитектурная декорация и малые формы церкви в Дранде

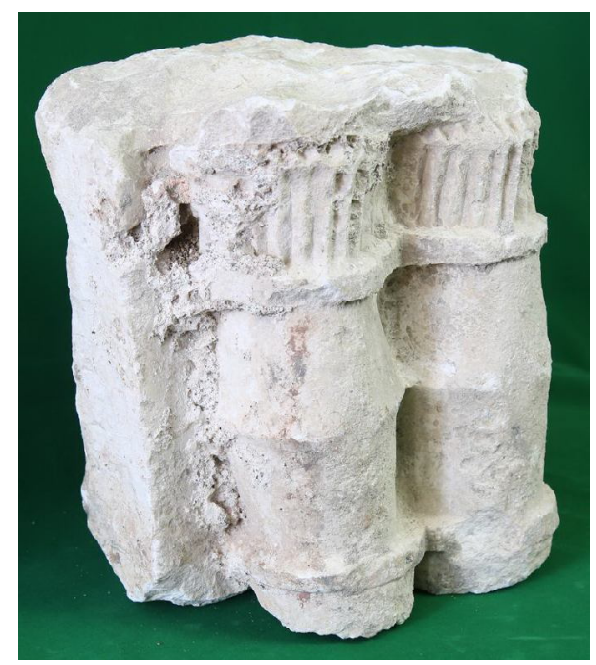

Рис. 7. Фрагмент архитектурной декорации из фондов Церковно-археологического музея Священной Метрополии Абхазии (Новый Афон). Известняк

Fig. 7. Fragment of architectural decoration from the funds of the Church and Archaeological Museum of Holy Metropolis of Abkhazia (New Athos). Limestone

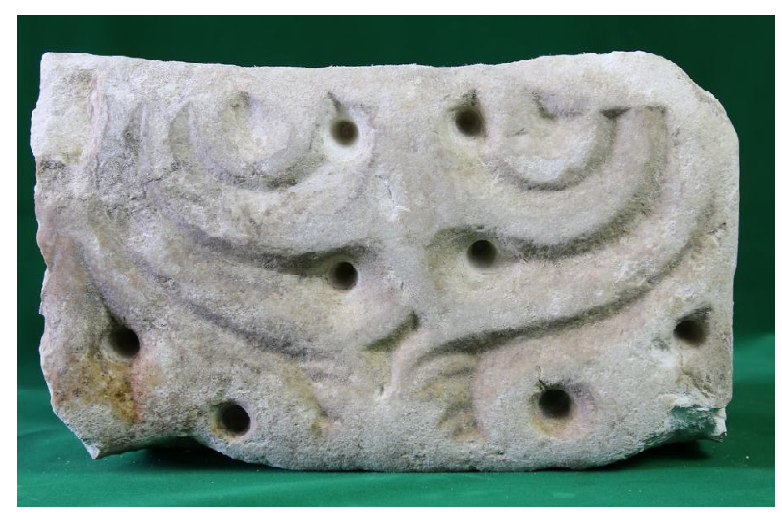

Рис. 8. Мраморная деталь из фондов Церковно-археологического музея Священной Метрополии Абхазии (Новый Афон). Известняк

Fig. 8. Marble item from the funds of the Church and Archaeological Museum of Holy Metropolis of Abkhazia (New Athos). Limestone

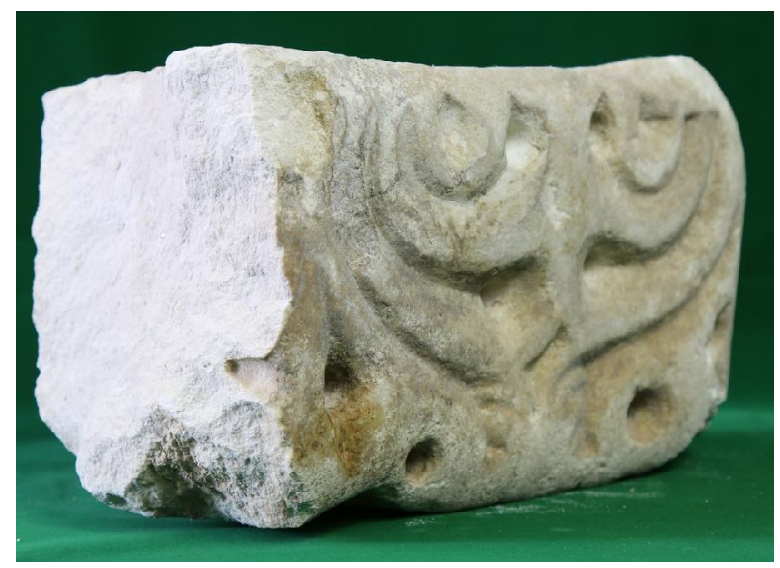

Рис. 9. Мраморная деталь из фондов Церковно-археологического музея Священной Метрополии Абхазии (Новый Афон). Известняк

Fig. 9. Marble item from the funds of the Church and Archaeological Museum of Holy Metropolis of Abkhazia (New Athos). Limestone 


\section{ВОПРОСЫ КУЛЬТУРЫ ВИЗАНТИИ}

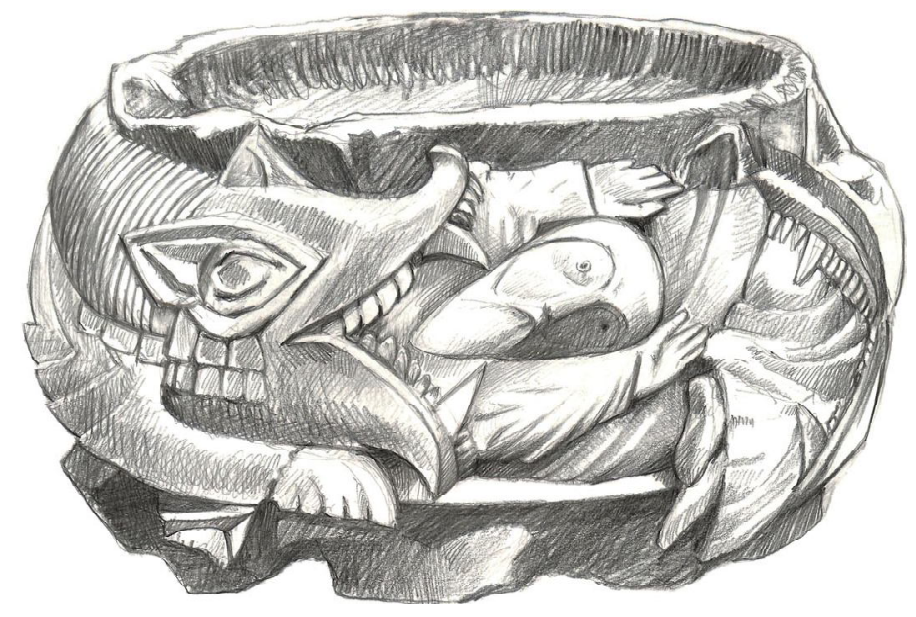

Рис. 10. Прорисовка сцены с пророком Ионой, поглощаемым китом, на фрагменте из фондов Церковно-археологического музея Священной Метрополии Абхазии (Новый Афон). Художник Б. Джапуа

Fig. 10. Drawing of a scene with the prophet Jonah, absorbed by the whale, on a fragment from the funds of the Church and Archaeological Museum of Holy Metropolis of Abkhazia (New Athos). Artist B. Japua

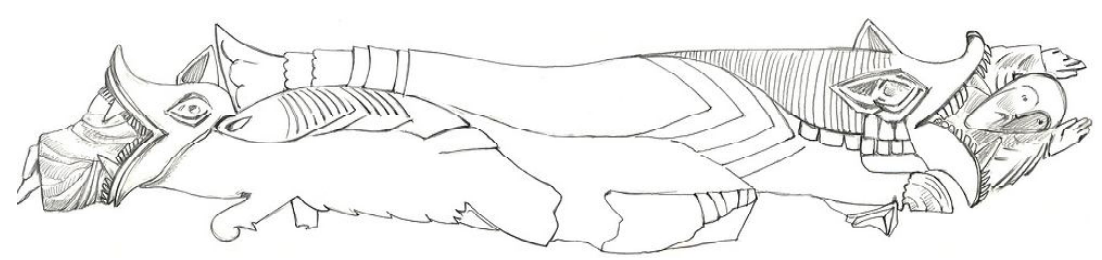

Рис. 11. Прорисовка сцены с пророком Ионой, поглощаемым китом, на фрагменте из фондов Церковно-археологического музея Священной Метрополии Абхазии (Новый Афон). Художник Б. Джапуа

Fig. 11. Drawing of a scene with the prophet Jonah, absorbed by the whale, on a fragment from the funds of the Church and Archaeological Museum of Holy Metropolis of Abkhazia (New Athos). Artist B. Japua 


\section{СПИСОК ЛИТЕРАТУРЫ}

1. Аладашвили, Н. А. Монументальная скульптура Грузии. Фигурные рельефы V-XI веков / Н. А. Аладашвили. - М. : Искусство, 1977. - 275 с.

2. Алибегашвили, Г. В. Рельефная плита из окрестностей Сухуми / Г. В. Алибегашвили // Сообщения Академии наук Грузии. - 1951. - XII, № 8. C. 511-515.

3. Виноградов, А. Ю. Дранда / А. Ю. Виноградов // Православная энциклопедия. Т. 17. - М. : Церковно-науч. центр «Православная энциклопедия», 2007.- С. 129-131.

4. Дудочкин, Б. Н. Об изображении «кита» пророка Ионы в росписи Андрея Рублева и Даниила 1408 г. в Успенском соборе Владимира и в миниатюрах Евангелия группы Хитрово / Б. Н. Дудочкин // Неизвестные произведения. Новые открытия : сб. науч. ст. к юбилею Музея имени Андрея Рублева. М. : Музей им. А. Рублева, 2017. - С. 116-135.

5. Ендольцева, Е. Ю. Разные интерпретации одного сюжета в средневековом христианском изобразительном искусстве / Е. Ю. Ендольцева, А. Ю. Виноградов // Восток. Афро-азиатские общества: история и современность. - 2016. - № 6. C. $90-97$.

6. Ендольцева, Е. Ю. Об одном необычном изображении «Сна Иосифа» / Е. Ю. Ендольцева // Библейские и литургические темы и образы в искусстве Востока и Запада: диалог культур, традиция и современность. - М. : Изд. центр РГГУ, 2017. С. 176-181.

7. Ендольцева, Е. Ю. Синкретизм христианских и дохристианских верований на примере архитектурной пластики Северного Кавказа / Е. Ю. Ендольцева // Историко-культурное наследие Юга России (Научно-практическая конференция, г. Ставрополь, 9 февр. 2015 г). - М. : Науч. о-во кавказоведов ; Кн. мир, 2015. - С. 271-280.

8. Ендольцева, Е. Ю. Алтарная преграда из церкви в Дранде: новые данные / Е. Ю. Ендольцева, архимандрит Дорофей Дбар // XXX «Крупновские чтения» по археологии Северного Кавказа. Кавказ в системе культурных связей Евразии в древности и Средневековье : материалы Междунар. науч. конф. г. Карачаевск, 22-29 апр. 2018. - Карачаевск : [б. и.], 2018. - C. 456-459.

9. Казарян, А. Ю. Тхаба-Ерды: к вопросу о датировке церкви и ее месте в средневековом зодчестве Кавказа / А. Ю. Казарян, Д. В. Белецкий // Вестник археологического центра. - 2009. - Вып. III. C. 50-94.

10. Меписашвили, Р. С. Архитектура нагорной части исторической провинции Грузии - Шида Картли / Р. С. Меписашвили, В. Цинцадзе. - Тбилиси : Мецниереба, 1975. - 198 с.
11. Саблин, С. Древний генуэзский храм в укреплении Дранды / С. Саблин // Кавказ. - 1846. № 8. - C. 32 .

12. Уварова, П. С. Христианские памятники / П. С. Уварова // Материалы по археологии Кавказа. - 1894. -Вып. 4. - С. 1-197, [122] с. ил.

13. Хрушкова, Л. Г. Раннехристианские памятники Восточного Причерноморья (IV-VII вв.) / Л. Г. Хрушкова. - М. : Наука, 2002. - 500 с.

14. Хрушкова, Л. Г. Скульптура раннесредневековой Абхазии V-X вв. / Л. Г. Хрушкова. - Тбилиси : Мецниереба, 1980. - 126 с.

15. Шмерлинг, Р. О. Малые формы в архитектуре средневековой Грузии / Р. О. Шмерлинг. - Тбилиси : Изд-во АН Грузии, 1962. - 292 с.

16. Bovini, G. Repertorium der christlich-antiken Sarkophage. I. Rom und Ostia. Textband und Tafelband / G. Bovini, H. Brandenburg. - Wiesbaden : F. Steiner, 1967. $-441 \mathrm{p}$.

17. Dadiani, T. Medieval Georgian sculpture / T. Dadiani, T. Khundadze, E. Kvachatadze.-Tbilisi : George Chubinashvili National Research Centre for Georgian Art History and Heritage Preservation, 2017. $-376 \mathrm{p}$.

18. Dubois de Montpéreux, F. Voyage autour du Caucase, chez les Tcherkesses et les Abkhases, en Colchide, en Géorgie, en Arménie et en Crimée / F. Dubois de Montpéreux. - Paris : Libr. de Gide, 1839. - Vol. I. - 435 p.

19. Hakobyan, Z. The Senmurv and Other Mythical Creatures with Sasanian Iconography in the Medieval Art of Armenia and Transcaucasia Fabulous Creations and Spirits in Ancient Iran. University of Venice / Z. Hakobyan, L. Mikaelyan (forthcoming).

20. Khroushkova, L. Les monuments chrétiens de la côte orientale de la mer Noire. Abkhazie IV-XIV siècles / L. Khroushkova. - Turnhout : Brepols, 2006. - 340 p. 21. Medieval Georgian Ecclesiastical Art in Georgian National Museum / ed. by N. Burchuladze. Tbilisi : Cezanne, 2012. - 293 p.

\section{REFERENCES}

1. Aladashvili N.A. Monumentalnaya skulptura Gruzii. Figurnye relyefy $V$-XI vekov [Monumental Sculpture of Georgia. Figurative Compositions of the $5^{\text {th }}-11^{\text {th }}$ Centuries]. Moscow, Iskusstvo Publ., 1977. 275 p. (in Russian).

2. Alibegashvili G.V. Relyefnaya plita iz okrestnostey Sukhumi [Carved Slab from the Surroundings of Sukhumi]. Soobshcheniya Akademii nauk Gruzii [Reports of the Academy of Sciences of Georgia], 1951, vol. 12, no. 8, pp. 511-515 (in Russian).

3. Vinogradov A.Yu. Dranda. Pravoslavnaya entsiklopediya [Orthodox Encyclopedia]. Moscow, 
Tserkovno-nauch. tsentr "Pravoslavnaya entsiklopediya”, 2007, vol. 17, pp. 129-131 (in Russian).

4. Dudochkin B.N. Ob izobrazhenii «kita» proroka Ioni v rospisi Andreya Rubleva i Daniila 1408 v Uspenskom sobore Vladimira i v miniaturakh Evangeliya gruppy Khitrovo [About one representation of prophet Jonas's «whale» in the painting of Andrew Rublev and Daniel of 1408 from the cathedral of Dormition in Vladimir and from the miniatures of Evangel of Hitrovo group]. Neizvestnye proizvedeniya. Novye otkrytiya: sb. nauch. st. $k$ yubileyu muzeya imeni Andreya Rubleva [Unknown Works. New Discoveries. Collection of Papers for the Jubilee of the Andrey Rublev Museum]. Moscow, Muzey im. A. Rubleva Publ., 2017, pp. 116-135 (in Russian).

5. Endoltseva E.Y., Vinogradov A.Yu. Raznye interpretatsii odnogo syuzheta $\mathrm{v}$ srednevekovom khristianskom izobrazitelnom iskusstve [Different Interpretations of One Subject in Medieval Christian Art]. Vostok. Afro-aziatskie obsestva: istoriya $i$ sovremennost [The East. Afro-Asian Societies: History and Modernity], 2016, no. 6, pp. 90-97 (in Russian).

6. Endoltseva E.Yu. Ob odnom neobychnom izobrazhenii "Sna Iosifa" [About One Unusual Representation of Joseph's Dream]. Bibleyskie $i$ liturgicheskie temy $i$ obrazy $v$ iskusstve Vostoka $i$ Zapada: dialog kultur, traditsiya i sovremennost [Biblical and Liturgical Themes and Circumcisions in the Art of the East and the West: the Dialogue of Culture, Traditions and Modernity]. Moscow, Izd. tsentr RGGU Publ., 2017, pp. 176-181 (in Russian).

7. Endoltseva E.Yu. Sinkretism khristianskikh i dokhristianskikh verovaniy na primere arkhitekturnoy plastiki Severnogo Kavkaza [Syncretism of Christian and Pre-Christian Beliefs on the Example of Architectural Decoration of the Northern Caucasus]. Istoriko-kulturnoe nasledie Yuga Rossii (Nauchnoprakticheskaya konferetsiya, g. Stavropol, 9 fevr. 2015 g.) [Historical and Cultural Heritage of the South of Russia (Scientific and Practical Conference. Stavropol, 9 February 2015)]. Moscow, Knizhnyy mir Publ., 2015, pp. 271-280 (in Russian).

8. Endoltseva E. Yu., archimandrit Dorofey Dbar. Altarnaya pregrada iz tserkvi v Drande: novye dannye [Altar Barrier from Dranda Church: New Findings]. XXX «Krupnovskie chteniya»po arkheologii Severnogo Kavkaza. Kavkaz v sisteme kulturnykh svyazey Evrazii $v$ drevnosti $i$ Srednevekove: materialy Mezdunar. nauch. konf. Karachaevsk, 22-29 apr. 2018 [The 30 ${ }^{\text {th }}$ Krupnovsky Readings on the Archaeology of the North Caucasus. Caucasus in the System of Cultural Ties of Eurasia in Antiquity and the Middle Ages. Proceedings of Technical Scientific Conference.
Karachaevsk, 22-29April 2018]. Karachaevsk, 2018, pp. 456-459 (in Russian).

9. Kazaryan A. Yu., Beletskiy D.V. Thaba-Erdi: k voprosu o datirovke tserkvi i ee meste v srednevekovom zodchestve Kavkaza [Thaba-Erdi: about the Date of the Church and Its Place in the Medieval Architecture of Caucasus]. Vestnik arkheologicheskogo tsentra [Science Journal of Archaeological Centre], 2009, vol. 3, pp. 50-94 (in Russian).

10. Mepisashvili R.S., Tsintsadze V. Arkhitektura nagornoy chasti istoricheskoy provintsii Gruzii Shida Kartli [Architecture of Mountain Region of Georgia - Shida Kartli]. Tbilisi, Metsniereba Publ., 1975. 198 p. (in Russian).

11. Sablin S. Drevniy genuezskiy khram v ukreplenii Drandy [Ancient Genoese Church in Dranda Fortress]. Kavkaz, 1846, no. 8, p. 32 (in Russian).

12. Uvarova P.S. Khristianskie pamyatniki [Christian Monuments]. Materialy po arkheologii Kavkaza [Materials on the Archaeology of the Caucasus], 1894, vol. 4, pp. 1-197, [122] p. il. (in Russian).

13. Khrushkova L.G. Rannekhristianskie pamyatniki Vostochnogo Prichernomorya (IV-VII vv.) [Early Christian Monuments of the Eastern Coast of the Black Sea of the $4^{\text {th }}-7^{\text {th }}$ Centuries]. Moscow, Nauka Publ., 2002. 500 p. (in Russian).

14. Khrushkova L.G. Skulptura rannesrednevekovoy Abkhazii $V-X v v$. [Sculpture of Early Medieval Abkhazia in the $5^{\text {th }}-10^{\text {th }}$ Centuries]. Tbilisi, Metsniereba Publ., 1980. 126 p. (in Russian).

15. Shmerling R.O. Malye formy v arkhitekture srednevekovoy Gruzii [Small Forms in Architecture of Medieval Georgia]. Tbilisi, Izd-voAN Gruzii Publ., 1962. 292 p. (in Russian).

16. Bovini G., Brandenburg H. Repertorium der christlich-antiken Sarkophage. Rom und Ostia. Textband und Tafelband. Wiesbaden, F. Steiner, 1967, vol. I. 441 p.

17. Dadiani, T., Khundadze T., Kvachatadze E. Medieval Georgian sculpture. Tbilisi, George Chubinashvili National Research Centre for Georgian Art History and Heritage Preservation, 2017. 376 p.

18. Dubois de Montpéreux F. Voyage autour du Caucase, chez les Tcherkesses et les Abkhases, en Colchide, en Géorgie, en Arménie et en Crimée. Paris, Libr. de Gide, 1839, vol. I. 435 p.

19. Hakobyan Z., Mikaelyan L. The Senmurv and Other Mythical Creatures with Sasanian Iconography in the Medieval Art of Armenia and Transcaucasia Fabulous Creations and Spirits in Ancient Iran. University of Venice (forthcoming).

20. Khroushkova L. Les monuments chrétiens de la côte orientale de la mer Noire. Abkhazie IVXIV siècles. Turnhout, Brepols, 2006. 340 p.

21. Burchuladze N., ed. Medieval Georgian Ecclesiastical Art in Georgian National Museum. Tbilisi, Cezanne, 2012. 293 p. 


\section{Information about the Authors}

Ekaterina Yu. Endoltseva, Candidate of Sciences (History of Art), Senior Researcher, Institute of Oriental Studies, RAS, Rozhdestvenka St., 12, 107031 Moscow, Russian Federation, kendoltseva@ivran.ru, https://orcid.org/0000-0003-1558-2819

Dorotheos Dbar (Archimandrite), Doctor of Theology, Aristotle University, Thessaloniki, Greece; Senior Researcher, Department of History, Abkhazian Institute for Humanities, Academy of Sciences of Abkhazia, Aidgilara St., 44, 384900 Sukhumi,Abkhazia, dbardorotheos@gmail.com, https://orcid.org/0000-0002-8133-6379

\section{Информация об авторах}

Екатерина Юрьевна Ендольцева, кандидат искусствоведения, старший научный сотрудник отдела сравнительного культуроведения, Институт востоковедения РАН, ул. Рождественка, 12, 107031 г. Москва, Российская Федерация, kendoltseva@ivran.ru, https:/orcid.org/0000-0003-1558-2819

Дорофей Дбар (архимандрит), доктор богословия, Университет им. Аристотеля, г. Салоники, Греция; старший научный сотрудник отдела истории, Абхазский институт гуманитарных исследований Академии наук Абхазии, ул. Аидгылара, 44, 384900 г. Сухум, Абхазия, dbardorotheos@gmail.com,https://orcid.org/0000-0002-8133-6379 